\title{
MAGNESIUM IN NORTH AMERICA: A CHANGING LANDSCAPE
}

Susan Slade

US Magnesium LLC; 238 North 2200 West; Salt Lake City, UT 84116, USA

Keywords: magnesium market, North America

\begin{abstract}
The changing landscape of North American manufacturing in the context of global competition is impacting the market of all raw materials, including magnesium. Current automotive fuel economy legislation and pending legislation on the emissions of greenhouse gases are impacting magnesium's largest consuming industries, such as aluminum, automotive components, steel and transition metals. These industries are all considering innovative ways to efficiently incorporate the needed raw materials into their processes. The North American magnesium market differs from other regions based on maturity, supply streams, changing manufacturing capabilities and trade cases, combined with the transformation of North American manufacturing.

The impact of these factors on the supply/demand dynamics of the North American magnesium market in both the short and longterm will be reviewed. The influence of new applications, products, and legislative changes are considered in the equation.
\end{abstract}

